\title{
Responses of Closely Related Bush Blue Lake Snap Bean Cultivars to Increasing Concentrations of Ozone
}

\author{
G. Eason' \\ North Carolina State University, Raleigh, NC 27695 \\ R.A. Reinert ${ }^{2}$ \\ U.S. Department of Agriculture, Agricultural Research Service, Raleigh, NC 27695 \\ Additional index words. Phaseolus vulgaris, air pollution, pod yield, open-top chambers
}

\begin{abstract}
Eight Bush Blue Lake type snap bean (Phaseolus vulgaris L.) lines and cultivars with similar genetic backgrounds were container-grown to green-pod maturity in open-top field chambers while being exposed to chronic doses of $0_{3}$ for 7 hours $\cdot$ day $^{-1}$ for 42 consecutive days. Treatments included charcoal-filtered air, nonfltered air, and $0.02,0.04$, or $0.08 \mathrm{ppm} \mathrm{O}_{3}$ added to nonfiltered air. Visible injury was estimated during the 2nd week of exposure and compared to the green pod yield data. The presence of four yield response groups, as determined via regression analysis, indicated the presence of variation for $0_{3}$ sensitivity in the germplasm pool, but all eight lines were $\mathrm{O}_{3}$ sensitive with yield losses at $0_{3}$ levels exceeding a 7-hour daily mean of $0.085 \mathrm{ppm}$. Foliar injury may be a good indicator of general yield loss; however, estimates of visible injury lack the precision necessary to distinguish subtle differences among a collection of $\mathrm{O}_{3}$-sensitive snap bean lines.
\end{abstract}

Bean has been established as an $\mathrm{O}_{3}$-sensitive horticultural crop (Davis and Kress, 1974; Haas, 1970; Middleton, 1956). Foliar injury has been characterized (Butler and Tibbitts, 1979; Haas, 1970; Middleton, 1956), and $\mathrm{O}_{3}$ has been shown to reduce yields (Heck et al., 1988; Heggestad et al., 1977, 1980; MacLean and Schneider, 1976; Reinert and Eason, 1986). Although immunity to $\mathrm{O}_{3}$ does not exist (Reinert et al., 1982), genetic variation exists within the germplasm pool (Butler and Tibbitts, 1979; Davis and Kress, 1974; Hucl and Beversdorf, 1982a, 1982b; Meiners and Heggestad, 1979; Reinert et al., 1984). Insensitivity to $\mathrm{O}_{3}$ has been identified among commercial cultivars (Butler and Tibbitts, 1979; Davis and Kress, 1974; Hucl and Beversdorf, 1982a; Meiners and Heggestad, 1979) and is especially prevalent among snap bean cultivars (Meiners and Heggestad, 1979). Most germplasm evaluations for $\mathrm{O}_{3}$ insensitivity have been based on ratings of foliar injury, but, where the selection pressure has been intense, snap bean cultivars classed as insensitive on the basis of their foliar response to $\mathrm{O}_{3}$ have also been classed as insensitive based on their yields under $\mathrm{O}_{3}$ stress in field experiments (Heck et al., 1988; R. A. R., unpublished).

Ambient levels of $\mathrm{O}_{3}$ have increased during the last few years, and, indeed, the oxidant problem in general is considered ubiquitous (Heck et al., 1983). Cultivars produced under polluted conditions may be the products of unintentional selection for insensitivity to $\mathrm{O}_{3}$ (Reinert et al., 1982). Bush Blue Lake snap

\footnotetext{
Received for publication 6 Oct. 1990. The authors appreciate the technical assistance of Tommy N. Gray, Ron Joyner, and John Dunning, the statistical advice of Susan Spruill, Matt Somerville, and John Rawlings, and the literature searches provided by Jeanie Hartman. We are also indebted to J.R. Baggett of Oregon State Univ. who provided seed for this study and insight into the pedigrees. The use of trade names or vendors in this publication does not imply endorsement by the U.S. Dept. of Agriculture or the North Carolina Agricultural Research Service of product names, nor criticism of similar ones not mentioned. The cost of publishing this paper was defrayed in part by the payment of page charges. Under postal regulations, this paper therefore must be hereby marked advertisement solely to indicate this fact.

'Dept. of Plant Pathology, Box 7616, North Carolina State Univ., Raleigh, NC 27695.

'U.S. Dept. of Agriculture/Agricultural Research Service, Dept. of Plant Pathology, North Carolina State Univ.
}

beans for processing, however, have been developed in one of the historically clean air basins of the United States, the Willamette Valley of Oregon, and the 'Blue Lake Pole' germplasm, frequently used in the Oregon State Univ. breeding program, has generally been classed as $\mathrm{O}_{3}$ sensitive (Meiners and Heggestad, 1979). Therefore, information on existing variability in this closely related gene pool would be useful in case of a decline of air quality in the Willamette Valley and in cases where bean breeders might desire to use the germplasm in $\mathrm{O}_{3^{-}}$ stressed areas. The objective of this research was to examine a collection of eight cultivars and/or breeding lines from the Oregon State Univ. snap bean breeding program for variability in yield response to $\mathrm{O}_{3}$ stress. A second objective was to determine whether visible injury response was correlated with yield response.

\section{Materials and Methods}

Seven snap bean lines developed by the Oregon State Univ. breeding program for commercial processing in the Willamette Valley ['Oregon (ORE) 1604', 'ORE 83', 'ORE 91', 'ORE 17', 'ORE 55', 'ORE 58', and 'OSU 4907'] and 'Bush Blue Lake (BBL) 290' (Asgrow Seed Co., Kalamazoo, Mich.) were evaluated for $\mathrm{O}_{3}$ sensitivity. Seed of each snap bean line were planted in a greenhouse supplied with charcoal-filtered (CF) air on 18 May in 236- $\mathrm{cm}^{3}$ styrofoam cups filled with Metro Mix 220 (W.R. Grace Co., Cambridge, Mass.), an artificial peat-perlite-vermiculite medium. Nine days after seeding, 30 uniform seedlings of each line were selected, transported to a field site $5 \mathrm{~km}$ south of Raleigh, N. C., and transplanted into 7.6-liter plastic containers filled with Metro Mix 220. Containers were placed in open-top chambers (Heagle et al., 1973), and seedlings were allowed to acclimate to field conditions for 3 days before $\mathrm{O}_{3}$ exposures. When exposures began, plants had one fully expanded trifoliolate leaf.

When temperatures exceeded 32C, plants were watered twice daily; otherwise, plants were watered once daily. The 1st week after transplanting, $500 \mathrm{ml}$ of a fertilizer solution $(3.2 \mathrm{~g}$ Peter's $20 \mathrm{~N}-20 \mathrm{P}-20 \mathrm{~K} /$ liter $\mathrm{H}_{2} \mathrm{O}$ ) was added to each container. Thereafter, $500 \mathrm{ml}$ of a more concentrated solution $(9.7 \mathrm{~g}$ Peter's $20 \mathrm{~N}-20 \mathrm{P}-20 \mathrm{~K} / \mathrm{liter} \mathrm{H}_{2} \mathrm{O}$ ) was added weekly to each container. 
When necessary, 1-naphthyl- $N$-methylcarbamate (carbaryl, 1.4 $\mathrm{c} \mathrm{m}^{3} \cdot$ liter $^{-1}$ ), tricyclohexylhydroxystannane (cyhexatin, 1.0 $\mathrm{cm}^{3} \cdot$ liter $^{-1}$ ), or O, S-dimethyl acetylphosphoramidothioate (acephate, $1.4 \mathrm{~g}$.liter ${ }^{-1}$, was used to control insects and mites.

Plants were exposed to $\mathrm{O}$, for $7 \mathrm{~h}$ each day (1000 to 1700 EDT) for 42 consecutive days beginning on 1 June. An $\mathrm{O}_{3}$ generator (OREC, Model 03B2-O; Ozone Research and Equip. Corp., Phoenix, Ariz.) using an electrostatic discharge converted dry $\mathrm{O}_{2}$ into $\mathrm{O}_{3}$ that then was dispensed into the open-top chambers via a control system (Heagle et al., 1979). The concentration of $\mathrm{O}_{3}$ at plant canopy level in each chamber and in the ambient air was monitored using a chemiluminescence $\mathrm{O}_{3}$ analyzer (Monitor Labs 8410; Monitor Labs, San Diego, Calif.) and shared-time system (Heagle et al., 1979). A seasonal (duration of the experiment) 7-h mean concentration was calculated for each $\mathrm{O}_{3}$ treatment and the ambient air.

The treatment design was a factorial with eight snap bean lines and five $\mathrm{O}_{3}$ levels: $\mathrm{CF}$ air, nonfiltered ambient air (NF), and $0.02,0.04$, or $0.08 \mathrm{ppm}_{3}$ added to NF air. The experimental design was a split-plot design with two blocks of the five $\mathrm{O}_{3}$ treatments. Thus, 10 open-top chambers were used in the experiment. Snap bean lines served as the subplot factor. One container of each line was randomly assigned to each third of each chamber. The total number of plants used in the experiment was 240 .

On 13 June, each primary leaf and -the first two trifoliolate leaves were rated for percent ( $0 \%$ to $100 \%$, in $5 \%$ increments) of the total leaf surface exhibiting $\mathrm{O}_{3}$ injury. These individual leaf readings were averaged for each plant, and the average was used for analyses. Marketable bean pods from all lines were harvested and weighed on 5, 14, and 15 July.

Yield data were examined for normality and homogeneity of variances among the individual snap bean lines. The Box-Cox Test (Rawlings, 1988) did not indicate that the data needed to be transformed. Total marketable bean fresh weight for each snap bean line was analyzed separately using analysis of variance (ANOVA), and variances among bean lines were not found to be different according to Bartlett's $x^{2}$ test of homogeneity (Steel and Torrie, 1980). Consequently, an overall ANOVA was run to test for a significant interaction between $\mathrm{O}_{3}$ treatments and bean lines. Regression analyses were then used to determine which lines differed in yield response to $\mathrm{O}_{3}$ dose. Initially, each bean line's response to $\mathrm{O}_{3}$ was regressed individually, and these response curves were then compared to each other. Since grouping of responses is somewhat arbitrary from a statistical viewpoint, common models were fit for lines based on similar genetic backgrounds and homogeneous response curves. Homogeneity was determined by testing the response errors in a "full" and "reduced" models test (Rawlings, 1988). Since the purpose of these models was to compute the residuals needed to test homogeneity and not to predict yield response to $\mathrm{O}_{3}$ dose, individual intercepts were allowed for each of the snap bean lines in any combined model, and models were expanded to the highest order necessary to result in insignificant lack of fit when compared to pure error. When two models of different polynomial order were combined, the higher order model was the common model first tested and then, if possible, reduced to a lower order common model by testing lack of fit. The success of a common response model to fit the data was determined with an $\mathrm{F}$ test (Rawlings, 1988). When a common model adequately fit the data from two or more lines, it replaced the original snap bean line models in subsequent tests. These procedures allowed de- termination of similarity between the bean lines and the parents present in their pedigrees.

Injury data were also examined for normality and heterogeneity of variances. The arcsin of the square root function was used to transform the injury data. Data from each $\mathrm{O}_{3}$ treatment were separately analyzed, and Bartlett's $x^{2}$ test (Steel and Torrie, 1980) found a lack of homogeneity among variances. Consequently, all further analyses were weighted by $1 / \mathrm{s}$ from the individual $\mathrm{O}_{3}$ analyses. Since injury data were only of interest in relation to yield response, bean lines with a common dose response model for yield were grouped for analysis. Variation due to snap bean lines was partitioned into variation among yield response groups and variation among snap bean lines within a group. For the purpose of comparison, a similar ANOVA was conducted on yield data.

\section{R e s u l t s}

The $7 \mathrm{~h}$-day I mean ambient $\mathrm{O}_{3}$ level for the duration of the exposure period was $0.073 \mathrm{ppm}$. Generally, activated charcoal filters can remove nearly all ambient $\mathrm{O}_{3}$, but through the growing season there was an ingress of ambient air containing $\mathrm{O}_{3}$ through the opening at the top of the chamber. Nonfiltered air chambers will have below ambient $\mathrm{O}_{3}$ due to some loss of $\mathrm{O}_{3}$ through the dust filter. Thus, the seasonal $7 \mathrm{~h}$-day $1 \mathrm{O}_{3}$ treatment means- $0.035,0.063,0.085,0.104,0.132 \mathrm{ppm}$ (for CF, $\mathrm{NF}$, and $0.02,0.04$, and $0.08 \mathrm{ppm}_{3}$ added to $\mathrm{NF}$ air, respectively) - were close to the expected values.

Snap bean lines yielded differently in response to $\mathrm{O}_{3}(P<$ $0.0001)$. Yield was sharply reduced for all lines in response to $\mathrm{O}_{3}$ levels exceeding $0.085 \mathrm{ppm}$ (Table 1). All of the bean lines had significant linear regression components, and four of the bean lines also had significant nonlinear components.

After individual regression analyses had been run for each snap bean line, lines were tested for similarity of response to $\mathrm{O}_{3}$ dose. Since pairing is arbitrary for statistical purposes, lines were compared beginning with those lines having more similar genetic backgrounds. Published pedigrees were used as aids in grouping (Baggett et al., 1981a, 1981b, 1981c, 1982, 1984; Frazier et al., 1972b), and portions of available pedigrees are shown in Fig. 1. 'ORE 58', one of the earliest bush beans with true Blue Lake qualities, has been used extensively in the Oregon State Univ. breeding program. Having evolved from a bulk planting of complex crosses, its exact pedigree is unknown, but contributing parents included 'Blue Lake Pole', 'Puregold',

Table 1. Effects of $\mathrm{O}_{3}$ dose on mean fresh weight yields $(\mathrm{g})$ of eight snap bean lines. ${ }^{z}$

\begin{tabular}{lccccc}
\hline \hline & \multicolumn{5}{c}{ Mean concn of $\mathrm{O}_{3}(\mathrm{ppm})$} \\
\cline { 2 - 6 } Bean line $^{\mathrm{y}}$ & 0.035 & 0.063 & 0.085 & 0.104 & 0.132 \\
\hline ORE 1604 & 267 & 225 & 241 & 116 & 56 \\
ORE 58 & 256 & 193 & 212 & 164 & 77 \\
ORE 55 & 304 & 288 & 246 & 142 & 78 \\
OSU 4907 & 286 & 238 & 194 & 112 & 54 \\
ORE 83 & 282 & 252 & 241 & 142 & 80 \\
ORE 17 & 260 & 222 & 191 & 108 & 51 \\
ORE 91 & 257 & 190 & 140 & 81 & 34 \\
BBL 290 & 297 & 215 & 160 & 95 & 85 \\
\hline
\end{tabular}

${ }^{2}$ Each value represents the mean of six plants.

y11 bean lines had significant linear regression components; the following bean lines also had significant nonlinear components: 'ORE 1604', 'ORE 58', 'ORE 55', and 'ORE 83'. 

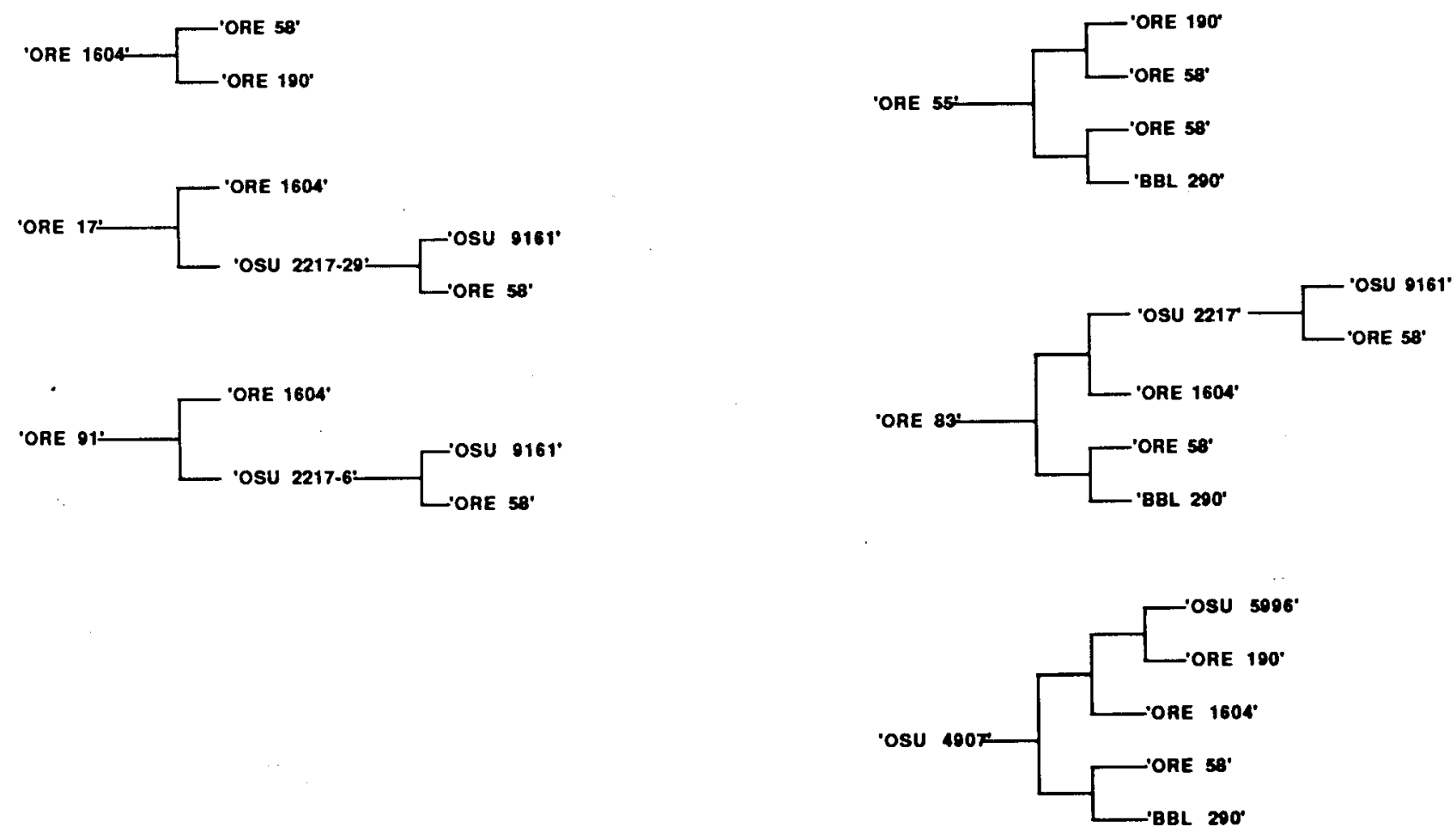

Fig. 1. Pedigrees for snap bean breeding lines 'ORE 1604' (Frazier et al., 1972b), 'ORE 17' (Baggett et al., 1981a), 'ORE 91' (Baggett et al., 1981c), 'ORE 55' (Baggett et al., 1982), 'ORE 83' (Baggett et al., 1981 b), and 'OSU 4907' (Baggett et al., 1984, references a sister line released instead of 'OSU 4907').

'Tendercrop', 'Gallatin 50', and 'Calpac 77' (Frazier et al., 1968). Its successor in the processing industry, 'ORE 1604' (Frazier et al., 1972b), was derived from selections from a cross between 'ORE 58' and 'ORE 190', another bush bean of complex parentage and with some 'Blue Lake' qualities (Frazier et al., 1972a). Because 'ORE 58' and 'ORE 1604' were closely related and were involved in the parentage of most of the other snap bean lines in this experiment (Fig. 1), a combined model was attempted for these two lines. However, the responses of these two bean lines were not similar enough to be combined into a single model.

'BBL 290' is a commercial cultivar and consequently does not have a published pedigree. It had been involved with 'ORE 58 ' and 'ORE 1604' in the parentage of some of the other lines in this experiment (Fig. 1). A common model could not be fit between 'BBL 290' and either of the other two parental lines, 'ORE 58' and 'ORE 1604'.

The five remaining snap bean lines were grouped by similarities in their pedigrees. 'ORE 17' (Baggett et al., 1981a) and 'ORE 91' (Baggett et al., 1981c), essentially sister lines, were the first nonparental lines tested for similar responses. As expected, a single model adequately expressed their yield response to $\mathrm{O}_{3}$. The pedigree for both 'ORE 83' (Baggett et al., 1981b) and 'OSU 4907' (Baggett et al., 1984, references a sister line released instead of 'OSU 4907') included 'BBL 290', 'ORE 58', and 'ORE 1604'. The pedigree for 'ORE 55' (Baggett et al., 1982) included 'BBL 290', 'ORE 58', and a cross between the parents of 'ORE 1604', 'ORE 190' and 'ORE 58'. A common model was fit first for 'ORE 83' and 'OSU 4907' and then for 'ORE 55' with 'ORE 83' and 'OSU 4907'. Finally, a common model was successfully fit for all five of the nonparental snap bean lines.

Common yield response models were attempted for the group of five progeny lines with each of the three parental lines, but no additional common models could be fit. Thus, the eight snap bean lines could be divided into three groups of one line each ('ORE 58', 'ORE 1604', 'BBL 290') and one group of five lines ('ORE 91', 'ORE 17', 'OSU 4907', 'ORE 83', and 'ORE 55') (Fig. 2).

Injury began as necrotic stippling, a response of bean to $\mathrm{O}_{3}$ that is well-defined (Butler and Tibbitts, 1979; Haas, 1970; Middleton, 1956). As the injury progressed, the foliage developed a bronze appearance on all of the bean lines except 'BBL 290', which became increasingly chlorotic and could be identified by its yellow foliage in chambers with $\mathrm{O}_{3}$ additions. Some bean plants had begun to defoliate in $0.132 \mathrm{ppm} \mathrm{O}_{3}$ before fruit maturity. Overall correlation between fresh weight yield and injury rating was large in absolute value and highly significant ( $R=-0.819, P=0.0001)$, indicating that foliar injury could be a good indicator of yield loss.

Based on the ANOVA for the injury ratings (Table 2), $\mathrm{O}_{3}$ dose significantly affected foliar injury, but injury response to $\mathrm{O}_{3}$ differed for the yield response groups, as indicated by the significant group $\times \mathrm{O}_{3}$ interaction. As with the fresh weight yield data, lines within the progeny group responded similarly to increasing $\mathrm{O}_{3}$ dose. Thus, 23 days before the first bean harvest, bean lines that would yield similarly in response to $\mathrm{O}_{3}$ stress were also showing similar increases in foliar injury in response to $\mathrm{O}_{3}$ dose. However, although ' $\mathrm{BBL} 290$ ' had the least injury for $\mathrm{O}_{3}$ concentrations $>0.063 \mathrm{ppm}$ (Table 3) of all of the groups, its yield was significantly and linearly reduced by $0_{3}$ (Fig. 2 ).

\section{Discussion}

As indicated by the four different responses identified (Fig. 2 ), variation in yield response to $\mathrm{O}_{3}$ dose existed among the 

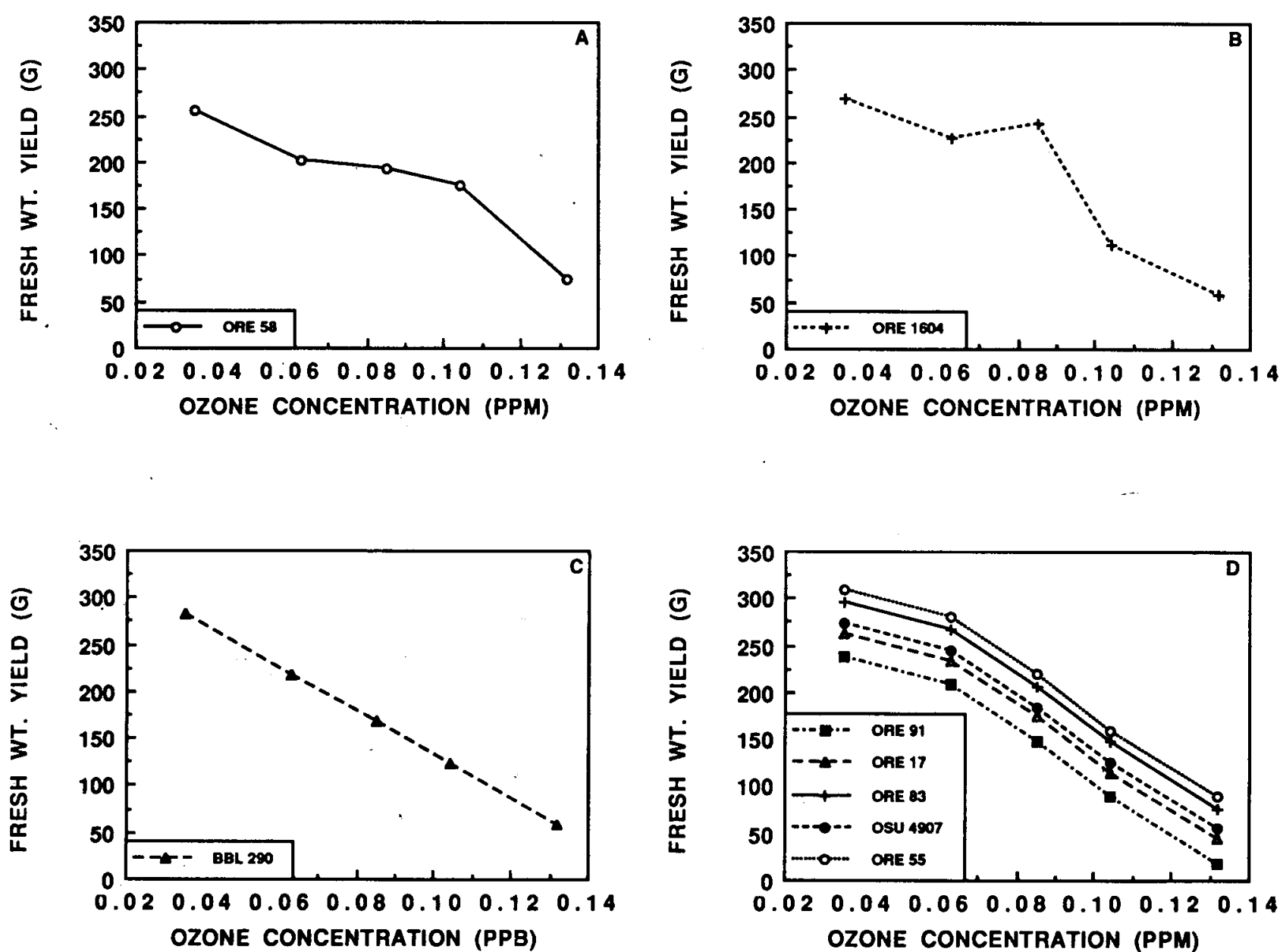

Fig. 2. Predicted values for the $7 \mathrm{~h}$.day' mean $\mathrm{O}_{3}$ levels from this experiment have been plotted for total marketable fresh weight yield (y) of the four groups of snap bean lines. Lines within the last group (D) have the same response curve but different yields. The model given for group D is for the first snap bean line ('ORE 91') listed in the group and is adjusted for the other four line(s) in that group via a dummy variable, 1 , which equals 1 for a particular line and otherwise equals $\mathrm{O}$ : $1_{1}$ represents 'ORE 17'; $\mathrm{I}_{2}$, 'OSU 4907'; $\mathrm{I}_{3}$, 'ORE 83'; and $1_{4}$, 'ORE 55'. Standard errors are from the regression error estimate. (A) 'ORE 58': y = $500-11,219(* 5426) \mathrm{O}_{3}+142,174$ (f 70,599) $\mathrm{O}_{3}^{2}$ : $618,203(\sim 279,753) \mathrm{O}_{3}^{3}$. (B) 'ORE 1604': $\mathrm{y}=2582-141,972( \pm 33,578) \mathrm{O}_{3}+2,976,870(* 692,236) \mathrm{O}_{3}{ }^{2}-25,833,124(* 5,895,275)$ $\mathrm{O}_{3}{ }^{3}+78,275,131( \pm 17,711,527) \mathrm{O}_{3}{ }^{4}$. (C) 'BBL 290': $\mathrm{y}=364-2310( \pm 265) \mathrm{O}_{3}$. (D) 'ORE 91', 'ORE 17', 'OSU 4907', 'ORE 83', and 'ORE 55': $\mathrm{y}=138.1+25.91_{1}+36.512+58.913+71.314+5745.6( \pm 2554) \mathrm{O}_{3}-94,783.2( \pm 33,231) \mathrm{O}_{3}{ }^{2}+336,283.5$ $( \pm 131,680) \mathrm{O}_{3}^{3}$.

eight snap bean lines in this experiment. Ozone sensitivity of the bean groups in this experiment was based on the rapidity of decline in yields in response to $\mathrm{O}_{3}$ dose. 'Gallatin 50 ' and 'Tendercrop', two lines involved in the parentage of 'ORE 58', have been classed as insensitive and moderately insensitive to $\mathrm{O}_{3}$, respectively (Davis and Kress, 1974; Heggestad et al., 1977, 1980; Meiners and Heggestad, 1979). Consequently, less sensitivity in 'ORE 58' and 'ORE 1604' to concentrations of $\mathrm{O}_{3}$ $<0.104 \mathrm{ppm}$ was not unexpected. 'BBL 290' is $\mathrm{O}_{3}$ sensitive (Heck et al., 1988; Heggestad et al., 1977, 1980) and has even been used previously as a standard of reference for sensitivity (Reinert et al., 1984). Therefore, its extreme sensitivity in this experiment "was also expected. 'ORE 91' and 'ORE 17' initially appeared to be more sensitive than the other three lines ('ORE 83', 'ORE 55', and 'OSU 4907') in their yield response group, but the difference was not statistically significant, i.e., one response model could be used to express the fresh weight yield of all five bean lines.

As previously stated, the equations given are not for predicting yields but for comparing responses to $\mathrm{O}_{3}$ among related snap bean lines. Therefore, biological interpretation was not considered when fitting the polynomial orders. In fact, bean lines may have a greater variation in response to $\mathrm{O}_{3}$ at very low doses than at high doses. Perhaps this variation could have been better addressed [particularly in the model for 'ORE 1604' (Fig. 2)] if additional $\mathrm{O}_{3}$ treatments between $0.032 \mathrm{ppm}$ and $0.085 \mathrm{ppm}$ had been included in this experiment.

Data from the 13 June injury rating agreed with yield data in that different yield response groups also exhibited different foliar injury responses to $\mathrm{O}_{3}$ dose, and bean lines yielding similarly in response to $\mathrm{O}_{3}$ dose showed similar foliar injury responses to $\mathrm{O}_{3}$. The rating method chosen for this experiment has been used effectively in determining extremes in bean sensitivity to $\mathrm{O}_{3}$ (Heck et al., 1988; Reinert et al., 1984) and should be a relatively objective method of estimating injury when used before the increased plant stress induced by fruiting results in natural senescence and possibly increased $\mathrm{O}_{3}$ injury (Simini et al., 1989). This early injury rating, however, did not indicate the extreme yield sensitivity of 'BBL 290'. Thus, as indicated by the negative correlation between yield and injury, bean plants 
Table 2. Sum of squares and probability values for total bean fresh weight and foliar injury ratings of eight snap bean breeding lines exposed to $\mathrm{O}_{3}{ }^{2}$.

\begin{tabular}{lrrrrr}
\hline \hline & & \multicolumn{2}{c}{$\begin{array}{c}\text { Total bean } \\
\text { fresh }\end{array}$} & \multicolumn{3}{c}{$\begin{array}{c}\text { Injury rating } \\
\text { 13 June }\end{array}$} \\
\cline { 3 - 7 } Source & df & \multicolumn{1}{c}{$\mathrm{SS}^{\mathrm{x}}$} & $\mathrm{P}>\mathrm{F}^{\mathrm{w}}$ & $\mathrm{S}$ & $\mathrm{S}^{\mathrm{x}} \mathrm{P}>\mathrm{F}^{\mathrm{w}}$ \\
\hline Block $(\mathrm{Blk})$ & 1 & 14,184 & 0.0290 & 1 & 0.6963 \\
$\mathrm{O}_{3}$ & 4 & $1,063,947$ & 0.0001 & 545 & 0.0030 \\
$\mathrm{Blk} \times \mathrm{O}_{3}$ & 4 & 5,099 & & 18 & \\
Group $(\mathrm{G})$ & 3 & 2,269 & 0.4705 & 2 & 0.4215 \\
Line $(\mathrm{G})$ & 4 & 94,239 & 0.0001 & 2 & 0.5677 \\
$\mathrm{O}_{3} \times \mathrm{G}$ & 12 & 55,581 & 0.0001 & 44 & 0.0002 \\
$\mathrm{O}_{3} \times \mathrm{Line}(\mathrm{G})$ & 16 & 16,437 & 0.3376 & 13 & 0.4709 \\
$\mathrm{Blk} \times \mathrm{O}_{3} \times \mathrm{G}+$ & & & & & \\
$\quad \mathrm{Blk} \times \mathrm{O}_{3} \times$ Line $(\mathrm{G})$ & 35 & 30,756 & & 28 & \\
Residual & 160 & 137,565 & & 136 & \\
\hline
\end{tabular}

${ }^{2} \mathrm{O}_{3}$ concentrations were $0.035,0.063,0.085,0.104$, and $0.132 \mathrm{ppm}$. y The primary leaves and the first two trifoliolates were rated for percentage of leaf surface injured by $\mathrm{O}_{3}$. Before analysis, the average of these ratings was transformed using the arcsin of the square root function and weighted by $1 / \mathrm{s}$ from analyses by $\mathrm{O}_{3}$ dose.

$\times \mathrm{SS}=$ sum of squares.

${ }^{w} \operatorname{Pr}>\mathrm{F}=$ Probability $>\mathrm{F}$.

Table 3. Effects of $\mathrm{O}_{3}$ dose on foliar injury of eight snap bean lines ${ }^{z}$ after 12 days of exposure.

\begin{tabular}{lccccc}
\hline \hline & \multicolumn{5}{c}{ Mean concn of $\mathrm{O}_{3}(\mathrm{ppm})$} \\
\cline { 2 - 6 } Bean line & 0.035 & 0.063 & 0.085 & 0.104 & 0.132 \\
\hline & \multicolumn{5}{c}{ Average foliar injury $(\%)^{\mathrm{y}}$} \\
ORE 1604 & 0.0 & 9.6 & 26.9 & 56.5 & 81.7 \\
ORE 58 & 0.0 & 11.7 & 24.4 & 36.2 & 52.7 \\
ORE 55 & 0.0 & 15.0 & 29.2 & 48.3 & 62.3 \\
ORE 4907 & 0.0 & 6.0 & 12.5 & 36.7 & 55.4 \\
ORE 83 & 0.0 & 9.0 & 20.2 & 41.2 & 45.4 \\
ORE 17 & 0.0 & 11.5 & 27.5 & 49.6 & 60.4 \\
ORE 91 & 0.0 & 23.8 & 39.0 & 51.7 & 59.8 \\
BBL 290 & 0.0 & 12.1 & 15.6 & 26.7 & 38.3 \\
\hline
\end{tabular}

${ }^{2}$ Each value represents the mean of six plants.

'Data were recorded on the primaries and first two trifoliolates as the percentage of the foliar surface injured by $\mathrm{O}_{3}$. Before analysis, data were transformed with the arcsin of the square root function and weighted by Us from analyses by $\mathrm{O}_{3}$ dose. Pretransformation values are shown.

expressing greater foliar $\mathrm{O}_{3}$ injury generally showed greater yield loss, but visible estimates of injury lacked the precision necessary for discerning the subtle variations in yield response among closely related, generally $\mathrm{O}_{3}$-sensitive bean lines.

Although different yield response groups were identified among the eight snap bean lines, all of the lines responded negatively to levels of $0_{3}>0.085 \mathrm{ppm}$, a level not very different from the mean ambient $\mathrm{O}_{3}$ level during this experiment. Another concern is that only 'ORE 58', the oldest of the bean lines examined in this experiment, had $<50 \%$ yield loss at 0.104 ppm $0_{3}$. Thus, all of the snap bean lines in this experiment were considered $0_{3}$ sensitive, and existing variability would probably be insufficient to prevent yield losses under $\mathrm{O}_{3}$ stress. Furthermore, this experiment indicates that as new snap bean lines with improved horticultural qualities and resistances to biotic diseases are developed in the absence of $\mathrm{O}_{3}$ stress, the genetic potential for $\mathrm{O}_{3}$ insensitivity is being lost. Since crop loss due to $\mathrm{O}_{3}$ sensitivity is one aspect of the global climate issue, the genetic basis for $\mathrm{O}_{3}$ sensitivity needs to be thoroughly studied for bean and other $\mathrm{O}_{3}$-sensitive crop species.

\section{Literature Cited}

Baggett, J. R., W.A. Frazier, and G.W. Varseveld. 1981a. 'Oregon 17' green bean. HortScience 16(2):228-229.

Baggett, J. R., W.A. Frazier, and G.W. Varseveld. 1981b. 'Oregon 83' green bean. HortScience 16(2):229.

Baggett, J. R., W.A. Frazier, and G.W. Varseveld. 1981c. 'Oregon 91' green bean. HortScience 16(2):230.

Baggett, J. R., W.A. Frazier, and G.W. Varseveld. 1982. 'Oregon 55' green bean. HortScience 17(1):96.

Baggett, J. R., W.A. Frazier, and G. W. Varseveld. 1984. 'Oregon Trail' green bean. HortScience 19(1):134.

Butler, L.K. and T.W. Tibbitts. 1979. Variation in ozone sensitivity and symptom expression among cultivars of Phaseolus vulgaris L. J. Amer. Soc. Hort. Sci. 104(2):208-210.

Davis, D. D'. and L. Kress. 1974. The relative susceptibility of 10 bean varieties to ozone. Plant Dis. Rptr. 58(1): 14-16.

Frazier, W. A., J.R. Baggett, H.J. Mack, A.A. Duncan, G.W. Varseveld, E.K. Vaughn, R. Bullock, J.B. Rodgers, and D. Booster. 1968. Processors to evaluate 'OSU 58' bush bean. Oregon Veg. Dig. 17(3):4-5.

Frazier, W.A., J.R. Baggett, H.J. Mack, G.W. Varseveld, A. Sheets, L. Martin, and E.K. Vaughn. 1972a. 'Oregon 190' bush green pod bean released. Oregon Veg. Dig. 21(3):1-2.

Frazier, W. A., J.R. Baggett, H.J. Mack, G. W. Varseveld, A. Sheets, L. Martin, and E.K. Vaughn. 1972b. 'Oregon 1604' bush green pod bean conditionally released. Oregon Veg. Dig. 21(3):2-4.

Haas, J.H. 1970. Relation of crop maturity and physiology to air pollution incited bronzing of Phaseolus vdgaris. Phytopathology 6O(3):407-410.

Heagle, A. S., D.E. Body, and W.W. Heck. 1973. An open-top field chamber to assess the impact of air pollution on plants. J. Env. Qual 2365-368.

Heagle, A. S., R.B. Philbeck, H.H. Rogers, and M.B. Letchworth. 1979. Dispensing and monitoring ozone in open-top field chambers for plant effects studies. Phytopathology 69: 15-20.

Heck, W. W., U. Blum, R.A. Reinert, and A.S. Heagle. 1983. Effects of air pollution on crop production, p. 333-350. In: W.J. Meudt (cd.). Strategies of plant reproduction (BARC Syrnp. No. 6.). Allanheld Osmun and Co, Totowa, N.J.

Heck, W. W., J.A. Dunning, R.A. Reinert, S.A. Prior, M. Rangappa, and P.S. Benepal 1988. Differential responses of four bean cultivars to chronic doses of ozone. J. Amer. Soc. Hort. Sci. 113(1):46--51.

Heggestad, H. E., R.K. Howell, and J.H. Bennett. 1977. The effects of oxidant air pollutants on soybeans, snap beans and potatoes. EPA Technical Rpt. EPA-600/3-77-128. EPA Corvallis.

Heggestad, H. E., A.S. Heagle, J.H. Bennett, and E. J. Koch. 1980. The effects of photochemical oxidants on the yield of snap beans. Atmospheric Env. 14:317-326.

Hucl, P. and W. D. Beversdorf. 1982a. The response of selected Phaseolus vulgaris L. crdtivars to ozone under controlled fumigation and ambient field levels. Can. J. Plant Sci. 62(3):561-569.

Hucl, P. and W.D. Beversdorf. 1982b. Tbe inheritance of ozone insensitivity in selected Phaseolus vulgaris L. populations. Can. J. Plant. Sci. 62(4):861865.

MacLean, D.C. and R.E. Schneider. 1976. Photochemical oxidants in Yonkers, New York: effects on yield of bean and tomato. J. Env. Qual. 5:75-78.

Meiners, J.P. and H.E. Heggestad. 1979. Evaluation of snap bean cultivars for resistance to ambient oxidants in field plots and to ozone in chambers. Plant Dis. Rptr. 63(4):273-277.

Middleton, J.T. 1956. Response of plants to air pollution. J. Air Pollut. Control. Assn. 6:1-4

Rawlings, J.O. 1988. Applied regression analysis: A research tool Wadsworth and Brooks/Cole Advanced Books and Software, Pacific Grove, Calif.

Reinert, R.A. and G. Eason. 1986. Responses of eight bush blue lake bean lines to increasing doses of $\mathrm{O}_{3}$. HortScience 21:787. (Abstr.)

Reinert, R. A., H.E. Heggestad, and W.W. Heck. 1982. Response and genetic modification of plants for tolerance to air pollutants, p. 259-292. In: M.N. Christiansen and C.F. Lewis (eds.). Breeding plants for less favorable environments. Wiley, New York.

Reinert, R.A., J.A. Dunning, W.W. Heck, P.S. Benepal, and M. Rangappa. 1984. Screening of bean (Phaseolus vulgaris) for sensitivity to ozone. HortScience 19(1):86-88.

Simini, M., J.E. Simon, R.A. Reinert, and G. Eason. 1989. Identification of ozone-induced injury on field-grown muskmelons. HortScience 24(6):909912.

Steel, R.G.D. and J.H. Torrie. 1980. Principles and procedures of statistics: A biometrical approach. McGraw-Hill, New York. 